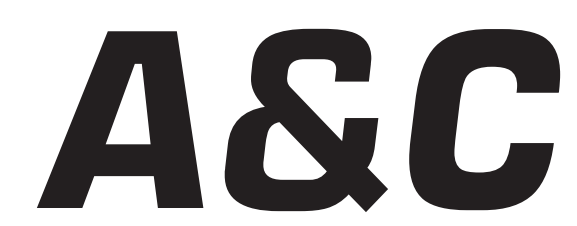

Revista de Direito Administrativo \& Constitucional

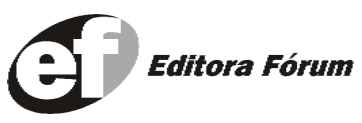

A\&C R. de Dir. Administrativo e Constitucional, Belo Horizonte, ano 5, n.19, p. 1-254, jan./mar. 2005 


\section{A\&C REVISTA DE DIREITO ADMINISTRATIVO E CONSTITUCIONAL}

\section{IPDA}

Instituto Paranaense

de Direito Administrativo

Direção Geral

Romeu Felipe Bacellar Filho

Direção Editorial

Paulo Roberto Ferreira Motta

Direção Executiva

Emerson Gabardo

Conselho de Redação

Edgar Chiuratto Guimarães

Adriana da Costa Ricardo Schier

Célio Heitor Guimarães

Conselho Editorial

Adilson Abreu Dallari

Alice Gonzáles Borges

Carlos Ari Sundfeld

Carlos Ayres Britto

Carlos Delpiazzo

Cármen Lúcia Antunes Rocha

Celso Antônio Bandeira de Mello

Clèmerson Merlin Clève

Clóvis Beznos

Enrique Silva Cimma

Eros Roberto Grau

Fabrício Motta

Guilhermo Andrés Muñoz (in memoriam)

Jaime Rodríguez-Arana Muñoz

Jorge Luís Salomoni
José Carlos Abraão
José Eduardo Martins Cardoso

José Luís Said

José Mario Serrate Paz

Juan Pablo Cajarville Peruffo

Juarez Freitas

Julio Rodolfo Comadira

Luís Enrique Chase Plate

Lúcia Valle Figueiredo

Manoel de Oliveira Franco Sobrinho

(in memoriam)

Marçal Justen Filho

Marcelo Figueiredo

Márcio Cammarosano

Maria Cristina Cesar de Oliveira
Nelson Figueiredo

Odilon Borges Junior

Pascual Caiella

Paulo Eduardo Garrido Modesto

Paulo Henrique Blasi

Paulo Neves de Carvalho (in memoriam)

Paulo Ricardo Schier

Pedro Paulo de Almeida Dutra

Regina Maria Macedo Nery Ferrari

Rogério Gesta Leal

Rolando Pantoja Bauzá

Sérgio Ferraz

Valmir Pontes Filho

Yara Stropa

Weida Zancaner

\footnotetext{
A246 A\&C Revista de Direito Administrativo e Constitucional. ano 3, n. 11, jan./mar. 2003. Belo Horizonte: Fórum, 2003.

Trimestral

ano 1, n.1, 1999 até ano 2, n.10, 2002 publicada pela Editora Juruá em Curitiba

ISSN: 1516-3210

1. Direito Administrativo. 2. Direito Constitucional. I. Fórum.
}

CDD: 342 CDU: 33.342

(c) Editora Fórum Ltda. 2005

Todos os direitos reservados. É proibida a reprodução total ou parcial, de qualquer forma ou por qualquer meio eletrônico ou mecânico, inclusive através de processos xerográficos, de fotocópias ou de gravação, sem permissão por escrito do possuidor dos direitos de cópias (Lei $n^{\circ}$ 9.610, de 19.02.1998).

Editora Fórum Ltda

Av. Afonso Pena, 2770 - 15\%16ªndar - Funcionários

CEP 30130-007 - Belo Horizonte/MG - Brasil

Tel.: 08007043737

Internet: www.editoraforum.com.br

e-mail: editoraforum@editoraforum.com.br
Editor responsável: Luís Cláudio Rodrigues Ferreira Projeto gráfico e diagramação: Luis Alberto Pimenta Revisora: Olga M. A. Sousa

Pesquisa jurídica: Fátima Ribeiro - OAB/MG 74868

Bibliotecária: Nilcéia Lage de Medeiros

CRB 1545/MG 6a região

Os conceitos e opiniões expressas nos trabalhos assinados são de responsabilidade exclusiva de seus autores.

Impressa no Brasil / Printed in Brazil

Distribuída em todo Território Nacional 


\title{
A Dimensão do Amicus Curiae no \\ Processo Constitucional Brasileiro: \\ Requisitos, Poderes Processuais e Aplicabilidade no Âmbito Estadual
}

\author{
Gustavo Binenbojm \\ Professor da Faculdade de Direito da Universidade do Estado do Rio de Janeiro- UERJ. Master of \\ Laws (LL.M.), Yale Law School. Mestre e Doutorando em Direito Público, UERJ. Procurador do \\ Estado, advogado e parecerista no Rio de Janeiro
}

\begin{abstract}
Sumário: 1 O amicus curiae e a sua configuração no direito brasileiro - 2 A possibilidade da intervenção do amicus curiae nas Representações por Inconstitucionalidade estaduais - 3 Requisitos para a participação do amicus curiae: relevância da matéria e representatividade dos postulantes - 4 Momento processual oportuno para a intervenção - $\mathbf{5}$ Poderes processuais reconhecidos ao interveniente admitido como amicus curiae no controle abstrato: manifestações escrita e oral e legitimidade recursal - 6 Síntese conclusiva
\end{abstract}

Este estudo tem por escopo, além de ampliar o debate sobre a importante e salutar figura do amicus curiae, provocar uma reflexão maior sobre as possibilidades do instituto no processo constitucional brasileiro. O presente artigo vem contribuir, específica e principalmente, com a análise de algumas questões processuais relativas ao tema ainda não muito desenvolvidas na doutrina.

Nos dois primeiros itens analisa-se o instituto conforme estabelecido no direito pátrio, bem como a sua aplicabilidade no controle abstrato de normas no âmbito estadual. Após, são desenvolvidas questões processuais, como a legitimidade da intervenção e a sua oportunidade, além de uma reflexão sobre os poderes processuais do amicus curiae, como o direito à sustentação oral, sua legitimidade recursal, dentre outros aspectos.

\section{0 amicus curiae e a sua configuração no direito brasileiro}

Costuma-se afirmar, sem que isso provoque maior polêmica, que a fiscalização abstrata da constitucionalidade se perfaz através de um processo

\footnotetext{
1 MENDES, Gilmar Ferreira. Controle de Constitucionalidade - Aspectos Jurídicos e Políticos. Saraiva, 1990, p. 250-251. Segundo o autor, o processo objetivo é "um processo sem sujeitos, destinado, pura e simplesmente, à defesa da Constituição. Não se cogita, propriamente, da defesa de interesse do requerente, que pressupõe a defesa de situações subjetivas."
}

A \& C R. de Dir. Administrativo e Constitucional, Belo Horizonte, ano 5, n. 19, p. 73-95, jan./mar. 2005 
objetivo. ${ }^{1}$ É que, ao contrário dos processos intersubjetivos, em que as partes contendem em torno de direitos ou interesses em conflito, o processo de controle abstrato da constitucionalidade não envolve pessoas ou interesses concretos, cingindo-se à aferição, em tese, da compatibilidade de uma norma determinada com outra que lhe é hierarquicamente superior. Diz-se, assim, que tal processo é objetivo no sentido de que não envolve situações jurídicas de caráter individual, destinando-se não à solução de litígios intersubjetivos, mas à guarda da Constituição. O Supremo Tribunal Federal adota placidamente a tese acima, ${ }^{2}$ não sem algumas mitigações em determinados pontos. ${ }^{3}$

Uma das decorrências dessa dita objetividade do processo de controle abstrato de constitucionalidade é a vedação genérica à intervenção de terceiros em feitos de tal natureza. Com efeito, não havendo direito subjetivo ou pretensão concreta deduzida pelo autor e resistida pelos réus, não poderia haver, segundo entendimento dominante, um interesse jurídico a ensejar a intervenção do terceiro na relação processual. ${ }^{4}$ Tal sempre foi o posicionamento do Supremo Tribunal Federal na matéria, ${ }^{5}$ fundado, de resto, no art. $169, \S 2^{\circ}$, do Regimento Interno da Corte, que vedava a intervenção assistencial nas representações por inconstitucionalidade.

A Lei ${ }^{\circ}$ 9.868/99, seguindo essa linha jurisprudencial e regimental, dispôs, no caput de seu art. $7^{\circ}$, que "não se admitirá intervenção de terceiros no processo de ação direta de inconstitucionalidade." Não obstante, os $\S \S 1^{\circ}$ e $2^{\circ}$ do art. $7^{\circ}$ instituíram saudável inovação, contemplando modalidades informais de intervenção de terceiros nos processos objetivos de controle de constitucionalidade. Confira-se o teor dos dispositivos mencionados:

Art. $7^{\circ}$

\footnotetext{
2 "(...) no exercício do controle em abstrato da norma jurídica, o Supremo Tribunal Federal desempenha função política, em cujo âmbito instauram-se relações processuais objetivas, que visam à tutela da ordem constitucional, sem vinculações quaisquer a situações de caráter individual, sendo a Corte investida numa competência de exclusão, consistente na remoção da manifestação estatal inválida do ordenamento jurídico, desempenhando, pois, o papel de legislador negativo." (RTJ, n. 131/1001 e 146/461).

${ }^{3}$ Uma dessas mitigações ou exceções consiste no instituto da pertinência temática. Embora a Constituição não o preveja, o Supremo Tribunal Federal construiu, ao longo dos últimos anos, uma robusta jurisprudência erigindo a pertinência temática como condição específica para que determinados órgãos e entidades se habilitem a manejar a ação direta de inconstitucionalidade. Tal condição consiste na relação de pertinência que deve existir entre os fins institucionais e atribuições do órgão ou entidade e o conteúdo do ato normativo impugnado por meio da ação direta. V., sobre o tema, BINENBOJM, Gustavo. A Nova Jurisdição Constitucional Brasileira, 2001, p. 142-143.

${ }_{4}^{4}$ Neste sentido, PALU, Oswaldo Luiz. Controle de Constitucionalidade, 1999, p. 216-217; VELOSO, Zeno. Controle Jurisdicional de Constitucionalidade, 1999, p. 88; MORAES, Alexandre de. Direito Constitucional, 1999, p. 571.

5 Vejam-se, por todos, RDA, 155/155, RDA, 157/266 e RTJ, 176/991.
} 
$\S 1^{\circ}$ Os demais titulares referidos no art. $2^{\circ}$ poderão manifestar-se, por escrito, sobre o objeto da ação e pedir a juntada de documentos reputados úteis para o exame da matéria, no prazo das informações, bem como apresentar memoriais. (vetado)

$\S 2^{\circ} \mathrm{O}$ relator, considerando a relevância da matéria e a representatividade dos postulantes, poderá, por despacho irrecorrível, admitir, observado o prazo fixado no parágrafo anterior, a manifestação de outros órgãos ou entidades. (grifo acrescentado).

Como se vê, o $\S^{\circ}$ do art. $7^{\circ}$ do estatuto que rege o sistema de controle abstrato de constitucionalidade $-\mathrm{o} \S 1^{\circ}$ restou vetado pelo Chefe do Poder Executivo ao argumento de que a abertura pretendida pelo preceito já seria alcançada pelo $\S 2^{\circ}$ - abrandou o sentido absoluto da vedação atinente à intervenção de terceiros, positivando, no ordenamento jurídico pátrio, a figura do amicus curiae (colaborador informal da Corte). ${ }^{6}$ Trata-se de inovação bem inspirada, que se insere no contexto de abertura da interpretação constitucional no país, permitindo que os indivíduos e grupos sociais participem ativamente das decisões do Supremo Tribunal Federal que afetem seus interesses. ${ }^{7}$ Além dos órgãos e entidades formalmente legitimados para a propositura da ação direta, poderão ser ouvidos quaisquer outros entes e organizações cuja representatividade autorize a sua manifestação, conforme decorre de evidente interpretação sistemática dos $\S \S 1^{\circ} \mathrm{e} 2^{\circ} .8$

A disciplina legal da figura do amicus curiae, de longa data admitida em outros ordenamentos jurídicos, ${ }^{9}$ já se encontrava contemplada no Brasil desde 1976, no art. 31 da Lei nú 6.385, de 07.12.1976, que admite a intervenção da Comissão de Valores Mobiliários - CVM em processos intersubjetivos nos quais se discutam questões de direito societário sujeitas, no plano administrativo, à competência dessa entidade autárquica federal.

\footnotetext{
6 Amicus curiae é o "amigo da Corte", aquele que lhe presta informações sobre matéria de fato e de direito, objeto da controvérsia. Sua função é chamar a atenção dos julgadores para alguma matéria que poderia, de outra forma, escapar-Ihe ao conhecimento. Um memorial de amicus curiae é produzido, assim, por quem não é parte no processo, com vistas a auxiliar a Corte para que esta possa proferir uma decisão acertada, ou com vistas a sustentar determinada tese jurídica em defesa de interesses públicos ou privados de terceiros, que serão indiretamente afetados pelo desfecho da questão. V. GIFIS, Steven H. Law Dictionary. Barron's Educational Series, Inc., 1975, p. 11-12.

7 COELHO, Inocêncio Mártires. As Idéias de Peter Häberle e a Abertura da Interpretação Constitucional no Direito Brasileiro. Revista de Direito Administrativo, n. 211, 1997, p. 132.

8 BINENBOJM, Gustavo. A Democratização da Jurisdição Constitucional e o Contributo da Lei n 9.868/99. In: SARMENTO, Daniel (Org.). O Controle de Constitucionalidade e a Lei $n^{\circ}$ 9.868/99, 2001, p. 159.

9 É da tradição do constitucionalismo norte-americano a admissão da figura do amicus curiae em processos alçados ao conhecimento da Suprema Corte, quando em discussão grandes questões constitucionais do interesse de toda a sociedade. O ingresso dos amici curiae serve, assim, para pluralizar o debate que, no sistema americano, é originariamente travado apenas entre as partes do processo. No âmbito da Suprema Corte norte-americana, a intervenção do amicus curiae é prevista na Rule 37 do Regimento Interno da Corte - Brief for an Amicus Curiae.
} 
O próprio Supremo Tribunal Federal, muito antes da edição da Lei $n^{\circ}$ 9.868/99, já admitia a juntada de memoriais por amicus curiae nas ações diretas de inconstitucionalidade. ${ }^{10}$

A inovação da Lei nÚ 9.868/99, entretanto, é dupla: (1 $\left.{ }^{\text {a }}\right)$ positivou-se, pela vez primeira entre nós, a figura do amicus curiae como interveniente em processo objetivo de controle de constitucionalidade, embora o STF, informalmente, já admitisse a sua manifestação por meio de memoriais; ( $\left.2^{\mathrm{a}}\right)$ ao contrário do caráter de intervenção neutra da CVM, fulcrada na Lei nÚ 6.385/76, nos processos de ação direta de inconstitucionalidade, o órgão ou entidade se habilitará para apresentar a sua visão da questão constitucional em testilha, oferecendo à Corte a sua interpretação, como partícipe ativo da sociedade aberta de intérpretes da Constituição. ${ }^{11}$

Com efeito, o propósito do art. 7Ú, §2Ú da Lei é claramente o de pluralizar o debate constitucional, permitindo que o Tribunal venha a tomar conhecimento, sempre que julgar relevante, dos elementos informativos e das razões constitucionais daqueles que, embora não tenham legitimidade para deflagrar o processo, serão destinatários diretos ou mediatos da decisão a ser proferida. Visa-se, ademais, a alcançar um patamar mais elevado de legitimidade nas deliberações do Tribunal Constitucional, que passará formalmente a ter o dever de apreciar e dar a devida consideração às interpretações constitucionais que emanam dos diversos setores da sociedade. ${ }^{12}$

O Supremo Tribunal Federal já teve a oportunidade, em diversas ocasiões, de sublinhar o propósito teleológico da norma inscrita no art. $7^{\circ}, \S 2^{\circ}$, da Lei $n^{\circ} 9.868 / 99$. Vale destacar, por seu conteúdo expressivo, a decisão proferida pela Suprema Corte nos autos da ADIN n 2.130-3 SC, ao admitir, na qualidade de amicus curiae, a Associação dos Magistrados Catarinenses - AMC, em demanda direta de inconstitucionalidade na qual se discutia a legitimidade jurídico-constitucional de resolução administrativa do Tribunal de Justiça do Estado de Santa Catarina. Naquela decisão, destacou o eminente Ministro Celso de Mello, verbis:

A admissão de terceiro, na condição de amicus curiae, no processo objetivo de controle normativo abstrato, qualifica-se como fator de legitimação social das decisões da Suprema Corte, enquanto Tribunal Constitucional, pois viabiliza, em

\footnotetext{
$\overline{{ }^{10} \text { Confira-se a ADIN n }}$ 748-4 RS (AgReg), rel. Min. Celso Mello. DJ, 18.11.1994, p. 31.392.

11 Sobre o tema, v. HÄBERLE, Peter. Hermenêutica Constitucional. A Sociedade Aberta de Intérpretes da Constituição:

Contribuição para a Interpretação Pluralista e Procedimental da Constituição. Sergio Fabris, 1997.

${ }^{12}$ Neste sentido, v. BIANCHI, Paolo. Un'Amicizia Interessata: L'amicus curiae Davanti Alla Corte Suprema Degli Stati Uniti. Giurisprudenza Costituzionale, Ano XI, Fasc. 6, 1995.
} 
obséquio ao postulado democrático, a abertura do processo de fiscalização concentrada de constitucionalidade, em ordem a permitir que nele se realize, sempre sob uma perspectiva eminentemente pluralística, a possibilidade de participação formal de entidades e de instituições que efetivamente representem os interesses gerais da coletividade ou que expressem os valores essenciais e relevantes de grupos, classes ou estratos sociais.

Em suma: a regra inscrita no art. $7^{\circ}, \S 2^{\circ}$, da Lei $n^{\circ} 9.868 / 99$ - que contém a base normativa legitimadora da intervenção processual do amicus curiae - tem por precípua finalidade pluralizar o debate constitucional. ${ }^{13}$

Já na ADIN n 2.777-8 SP, rel. Min. Celso de Mello, o Supremo Tribunal admitiu como amici curiae um grupo de empresas que postulavam manifestar-se sobre a constitucionalidade de lei do Estado de São Paulo que versava sobre a substituição tributária no ICMS. Naquela decisão, consignou a Corte, in verbis:

Não se pode perder de perspectiva que a regra inscrita no art. $7^{\circ}, \S 2^{\circ}$ da Lei $n^{\circ}$ 9.868/99 - que contém a base normativa legitimadora da intervenção processual do "amicus curiae" - tem por objetivo essencial pluralizar o debate constitucional, permitindo que o Supremo Tribunal Federal venha a dispor de todos os elementos informativos possíveis e necessários à resolução da controvérsia, visando-se, ainda, com tal abertura procedimental, superar a grave questão pertinente à legitimidade democrática das decisões emanadas desta Corte (GUSTAVO BINENBOJM, "A Nova Jurisdição Constitucional Brasileira”, 2001, Renovar; ANDRÉ RAMOS TAVARES, "Tribunal e Jurisdição Constitucional”, p. 71/94, 1998, Celso Bastos Editor; ALEXANDRE DE MORAES, "Jurisdição Constitucional e Tribunais Constitucionais", p. 64/81, 2000, Atlas), quando no desempenho de seu extraordinário poder de efetuar, em abstrato, o controle concentrado de constitucionalidade. ${ }^{14}$

A decisão de admitir ou não o amicus curiae é da competência do relator, a quem caberá aquilatar, de um lado, a relevância da matéria em discussão, e, de outro lado, a representatividade dos postulantes, para admitir ou não a manifestação do órgão ou entidade postulante. Na análise do binômio relevância-representatividade, deverá o relator levar em conta a magnitude dos efeitos da decisão a ser proferida nos setores diretamente afetados ou para a sociedade como um todo, bem como se o órgão ou entidade postulante congrega dentre seus afiliados porção significativa (quantitativa ou qualitativamente) dos membros do(s) grupo(s) social(is) afetado(s). Como afirmou o eminente Ministro Celso de Mello na ADIN 
$\mathrm{n}^{\mathrm{o}}$ 2.130-3 SC, a intervenção do amicus curiae, para legitimar-se, deve apoiar-se em razões que tornem desejável e útil a sua atuação processual na causa, em ordem a proporcionar meios que viabilizem uma adequada resolução do litígio." 15

Neste sentido, o STF já admitiu, na condição de amici curiae, a Associação dos Magistrados Catarinenses - $\mathrm{AMC},{ }^{16}$ o Instituto de Resseguros do Brasil - IRB,${ }^{17}$ o Ministério Público do Estado do Rio de Janeiro, ${ }^{18}$ a Companhia Energética de Brasília - CEB, ${ }^{19}$ a Confederação Nacional dos Trabalhadores na Agricultura - CONTAG,${ }^{20}$ dentre vários outros.

\section{A possibilidade da intervenção do amicus curiae nas Representações por Inconstitucionalidade estaduais}

Não pode haver dúvidas de que o art. $7^{\circ}, \S^{\circ}$, da Lei $n^{\circ} 9.868 / 99$, aplica-se aos processos de controle abstrato de constitucionalidade de âmbito estadual.

Com efeito, no esquema de partilha constitucional de competências, dispõe o art. 22, inciso I, da Lei Maior, que a competência para legislar sobre direito processual é privativa da União Federal. Vale transcrever o dispositivo constitucional, verbis:

\section{Art. 22. Compete privativamente à União legislar sobre:}

I - direito civil, comercial, penal, processual, eleitoral, agrário, marítimo, aeronáutico, espacial e do trabalho;

Note-se que a norma constitucional definidora da competência é de espectro amplo, referindo-se a direito processual indistintamente, sem especificar a área do processo que alcança. Assim, entende-se, placidamente, que só a lei federal pode dispor sobre todas as áreas do processo, seja ele civil, penal, do trabalho ou constitucional. Invocando-se, aqui, vetusta regra de hermenêutica, não cabe ao intérprete distinguir onde o legislador não o fez.

Por outro lado, o art. 24, inciso XI, da Constituição Federal estabelece competir concorrentemente à União, Estados e Distrito Federal legislar sobre "procedimentos em matéria processual". Como se sabe, as competências

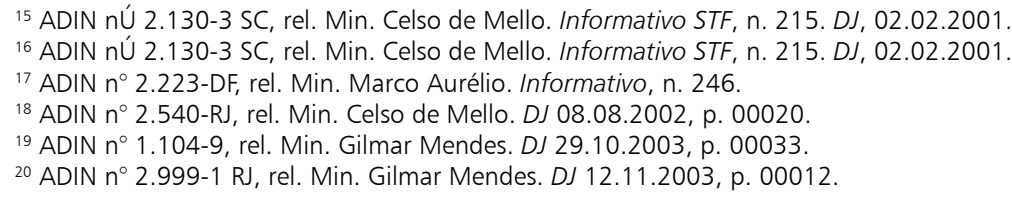


concorrentes previstas no art. 24 encontram-se submetidas às regras insculpidas nos $\S \S 1^{\circ}$ a $4^{\circ}$ do mesmo preceptivo constitucional. De acordo com tais regras, no âmbito da legislação concorrente, compete à União legislar sobre normas gerais sobre o assunto, restando aos Estados e ao DF exercer uma competência legislativa suplementar.

Assim, no que se refere às representações por inconstitucionalidade estaduais, incide plenamente a lei federal de regência (Lei $n^{\circ}$ 9.868/99), que trata tanto das normas processuais aplicáveis à ação direta de inconstitucionalidade como daquelas aplicáveis à ação declaratória de constitucionalidade. Esta é uma decorrência direta do art. 22, inciso I, da Carta da República. Aos Estados e ao DF, nos termos do art. 24, inciso XI c/c $\S \S 1^{\circ} \mathrm{e} 2^{\circ}$, compete suplementar a legislação federal sobre a matéria, adequando as normas gerais da Lei $n^{\circ} 9.868 / 99$ às peculiaridades e necessidades locais.

Este entendimento merece a chancela do mais autorizado magistério doutrinário sobre o tema. Destaque-se, dentre vários autores, a lição de André Ramos Tavares, que assim expõe sua posição, verbis:

É preciso, pois, esclarecer se essa lei, quando tratar da argüição estadual, haveria de ser igualmente estadual ou se, ao contrário, deverá ser seguida a lei federal de regência. A dúvida é, de resto, a mesma que se projeta quanto à lei que trata do processo e julgamento da ação direta de inconstitucionalidade e ação declaratória de constitucionalidade (Lei n ${ }^{\circ}$ 9.868/99).

Tem-se que, do ponto de vista das regras de processo, não há como desconhecer a competência privativa da União para legislar (art. 22, I, da Constituição Federal). Já sobre procedimentos em matéria processual têm os Estados competência concorrente com a União, vale dizer, esta tem a tarefa de traçar as diretrizes que serão especificadas pelos Estados (art. 24, XI e parágrafos, da Constituição Federal). ${ }^{21}$

Em abono da inteligência que aqui se adota, registre-se que a Lei $\mathrm{n}^{\circ}$ 9.868/99 cuidou, em seus arts. 29 e 30, de aspectos do controle de constitucionalidade aplicáveis no âmbito das unidades federadas. De fato, o art. 29 promoveu alteração no art. 482 do Código de Processo Civil para, precisamente, permitir a intervenção de outros interessados, na condição de amici curiae, nas argüições incidentais de inconstitucionalidade. Já o art. 30 disciplinou a ação direta de inconstitucionalidade de lei ou ato normativo do Distrito Federal, no âmbito daquela unidade federativa. $A$

${ }_{21}^{11}$ TAVARES, André Ramos. Curso de Direito Constitucional. Saraiva, 2002, p. 331.

A \& C R. de Dir. Administrativo e Constitucional, Belo Horizonte, ano 5, n. 19, p. 73-95, jan./mar. 2005 
aplicabilidade direta de tais dispositivos da Lei $n^{\circ} 9.868 / 99$ aos processos em curso perante os Tribunais de Justiça das Unidades da Federação é justificada pelo eminente Ministro Gilmar Mendes, um dos autores do Anteprojeto de Lei, com fundamento na competência privativa da União Federal para legislar sobre direito processual. ${ }^{22}$

Ora, diante de circunstâncias semelhantes há que se aplicar o mesmo direito. Se a norma federal vale para o controle abstrato de normas instaurado perante o Tribunal de Justiça do Distrito Federal, para aferição da constitucionalidade das normas distritais em face da Lei Orgânica do Distrito Federal, o mesmo modelo deve valer para as representações de inconstitucionalidade instauradas perante os Tribunais de Justiça dos demais Estados da Federação. Tal não impede, por evidente, que cada Estado, no exercício de sua competência legislativa em matéria de procedimentos, venha a editar normas específicas sobre representação por inconstitucionalidade, suplementando a Lei Federal $n^{\circ}$ 9.868/99.

Acrescente-se, ainda, em reforço do argumento, que o próprio Tribunal de Justiça do Estado do Rio de Janeiro já reconheceu a aplicabilidade da norma processual federal que prevê o amicus curiae em processos de sua competência. Tal se deu, v.g., no julgamento do Agravo de Instrumento $n^{\circ}$ 2002.002.19865, rel. Des. Nagib Slaibi Filho, 6 ${ }^{a}$ Câmara Cível, em que assim restou lavrado, verbis:

A aplicação pela analogia permitida pelo disposto no art. 126 do Código de Processo Civil do amicus curiae previsto no art. $6^{\circ}, \S 1^{\circ}$, da Lei ${ }^{\circ} 9.882$, de 3 de dezembro de 1999, esclarecendo-se os fatos e a relação jurídica vinculam as partes pela oitiva de funcionários da Agência Nacional de Telecomunicações, que se qualifica processualmente como terceira na lide. ${ }^{23}$

Consoante as razões acima expostas, entendo resta evidente a aplicabilidade do art. $7^{\circ}, \S 2^{\circ}$, da Lei $n^{\circ} 9.868 / 99$, que institucionaliza a figura do amicus curiae, aos processos de representação por inconstitucionalidade estaduais.

Por outro lado, conforme já anotado, é oportuno lembrar que, mesmo antes da positivação do instituto entre nós, o que se deu por meio da Lei $n^{\circ}$ 9.868/99, o Supremo Tribunal Federal já o admitia, autorizando a juntada de memoriais pelo amicus curiae em ações diretas de inconstitu-

\footnotetext{
${ }^{22}$ MENDES, Gilmar Ferreira; MARTINS, Yves Gandra da Silva. Controle Concentrado de Constitucionalidade - Comentários à Lei n 9.868, de 10.11.1999. Saraiva, 2001, p. 356.

${ }^{23}$ No mesmo sentido, Agravo de Instrumento n 2002.002.15736, rel. Des. Nagib Slaibi Filho, 6a Câmara Cível, TJ/RJ.
}

A \& C R. de Dir. Administrativo e Constitucional, Belo Horizonte, ano 5, n. 19, p. 73-95, jan./mar. 2005 
cionalidade. Veja-se, neste sentido, o ensinamento de Edgard Silveira Bueno Filho, in verbis:

Esse último dispositivo (art. $7^{\circ}, \S 2^{\circ}$ ) serviu para a consagração da presença do amicus curiae no processo de controle da constitucionalidade.

O uso do vocábulo "consagração" foi proposital, pois a Suprema Corte já havia, embora timidamente, admitido, antes da lei, a sua presença no processo de controle da constitucionalidade. É o que se viu no julgamento de Agravo Regimental em ADIN n ${ }^{\circ} 748-4$, quando, por unanimidade de votos, o Plenário do STF confirmou a decisão monocrática do eminente Ministro Celso de Mello e permitiu que um memorial, preparado por um colaborador informal, permanecesse juntado por linha ao processo. ${ }^{24}$

Deste modo, se mesmo antes da consagração formal do instituto do amicus curiae na Lei $\mathrm{n}^{\circ} 9.868 / 99$, o Supremo Tribunal já o adotava informalmente, nada impede que o Tribunal de Justiça do Estado do Rio de Janeiro o faça, em ordem a permitir a pluralização do debate constitucional e a democratização do processo de representação por inconstitucionalidade.

\section{Requisitos para a participação do amicus curiae: relevância da matéria e representatividade dos postulantes}

Conforme estabelece o $\S 2^{\circ}$ do art. $7^{\circ}$ da Lei $n^{\circ}$ 9.868/99 dispõe que "o relator, considerando a relevância da matéria e a representatividade dos postulantes, poderá, por despacho irrecorrível, admitir, observado o prazo fixado no parágrafo anterior, a manifestação de outros órgãos ou entidades."

Veja-se, em primeiro lugar, que, ao contrário do que exigia o $\$ 1^{\circ} \mathrm{do}$ art. $7^{\circ}$ (vetado pela Chefia do Executivo), o dispositivo em questão nãa exige que o amicus curiae seja legitimado para a propositura da ação direta de inconstitucionalidade. Essa é uma conclusão a que se chega através de uma singela interpretação sistemática do $\S 2^{\circ}$ em cotejo com o $\S 1^{\circ}$. Deveras, enquanto o $\S 1^{\circ}$ dispunha que "os demais titulares referidos no art. $2^{\circ}$ poderão manifestar-se, por escrito, sobre o objeto da ação...", o §2 se refere à manifestação de "outros órgãos ou entidades."

Daí só pode decorrer, logicamente, que o legislador cogitou, no $\S 1^{\circ}$, de permitir a atuação, como amici curiae, dos demais legitimados à propositura da ação direta, enquanto, no $\S 2^{\circ}$, permitiu a intervenção

\footnotetext{
${ }^{24}$ BUENO FILHO, Edgard Silveira. Amicus Curiae - A Democratização do Debate nos Processos de Controle de Constitucionalidade. Revista Diálogo Jurídico, n. 14, jun./ago. 2002. Disponível em: < http:// www. direitopublico.com. br>.
} 
de outros órgãos ou entidades que não se qualifiquem como legitimados a tal propositura, mas que, por sua notória representatividade e à vista da relevância da matéria, mereçam manifestar-se no processo.

O Supremo Tribunal Federal já teve a oportunidade de deixar claro seu entendimento nesse sentido ao admitir, como amici curiae, diversos órgãos e entidades, públicas e privadas, que não se qualificavam como legitimados à propositura da ação direta de inconstitucionalidade. Anotemse, como exemplos, a Associação dos Magistrados Catarinenses - AMC, ${ }^{25} \mathrm{O}$ Instituto de Resseguros do Brasil - IRB, ${ }^{26}$ o Ministério Público do Estado do Rio de Janeiro, ${ }^{27}$ a Companhia Energética de Brasília - CEB, ${ }^{28}$ dentre vários outros.

$\mathrm{Na}$ mesma toada segue a doutrina mais autorizada. Gilmar Ferreira Mendes e Yves Gandra Martins reconhecem que tanto os demais legitimados do art. $2^{\circ}$, quanto "outros órgãos ou entidades" têm o direito de manifestação na ação direta. ${ }^{29}$ Nelson Nery Júnior ensina que o rol de amici curiae é amplo, sendo que o relator poderá "admitir a manifestação de pessoa física ou jurídica, professor de direito, associação civil, cientista, órgão e entidade, desde que tenha respeitabilidade, reconhecimento científico ou representatividade para opinar sobre a matéria objeto da ação direta." ${ }^{0}$ Também Edgard Silveira Bueno Filho corrobora a tese, afirmando que, além dos legitimados para a propositura da demanda direta, "haverá sempre outras entidades de notória representatividade que, por isso, serão facilmente admitidas ao debate, dependendo apenas do tema discutido. É o caso das associações de magistrados, de advogados, de outros profissionais liberais, de empresários, de defesa de direitos humanos, de consumidores, do meio ambiente etc., quando o ato normativo questionado tiver relação com a atividade por eles desenvolvida." ${ }^{31}$

Em síntese, têm legitimidade para intervir como amicus curiae tanto os legitimados para a propositura de ADI a que se refere o art. $2^{\circ}$ da Lei $n^{\circ} 9.868 / 99$, quanto outras entidades e órgãos que, por sua notória representatividade e à vista da relevância da matéria, mereçam manifestar-se

${ }_{25}$ ADIN nÚ 2.130-3 SC, rel. Min. Celso de Mello. Informativo STF, n. 215. DJ, 02.02.2001.

${ }^{26}$ ADIN n².223-DF, rel. Min. Marco Aurélio. Informativo, n. 246.

${ }^{27}$ ADIN n² 2.540-RJ, rel. Min. Celso de Mello. DJ 08.08.2002, p. 00020.

${ }^{28}$ ADIN n 1.104-9, rel. Min. Gilmar Mendes. DJ 29.10.2003, p. 00033.

${ }^{29}$ MENDES, Gilmar Ferreira; MARTINS, Yves Gandra da Silva, op. cit., p. 158.

${ }^{30}$ NERY JÚNIOR, Nelson. Código de Processo Civil Comentado e Legislação Processual Civil em Vigor. 6. ed., 2003, p. 1.408

${ }^{31}$ BUENO FILHO, Edgard Silveira, op. cit., p. 6.

32 Em trabalho publicado em 2001, pela Editora Lumen Juris, adotei posição neste mesmo sentido ao afirmar: "Além dos órgãos e entidades formalmente legitimados para a propositura da alçao direta, 
no processo para torná-lo mais democrático.

A propósito da verificação do preenchimento dos requisitos, em outro estudo que escrevi sobre o tema, tive a ocasião de consignar que "na análise do binômio relevância-representatividade, deverá o relator levar em conta a magnitude dos efeitos da decisão a ser proferida nos setores diretamente afetados ou para a sociedade como um todo, bem como se o órgão ou entidade postulante congrega dentre seus afiliados porção significativa (quantitativa ou qualitativamente) dos membros do(s) grupo(s) social(is) afetado(s)." ${ }^{33}$ Edgard Silveira Bueno Filho entende que por relevância da matéria o legislador quis que o postulante demonstrasse a relação de relevância entre a matéria discutida e a atividade perseguida pela instituição, porquanto não há como se cogitar de um processo objetivo de controle de constitucionalidade que verse matéria irrelevante. ${ }^{34}$

\section{Momento processual oportuno para a intervenção}

$\mathrm{O} \S 2^{\circ}$ do art. $7^{\circ}$ da Lei $\mathrm{n}^{\circ} 9.868 / 99$ dispõe que o relator poderá, "por despacho irrecorrível, admitir, observado o prazo fixado no parágrafo anterior, a manifestação de outros órgãos ou entidades." Já o $1^{\circ}$ do artigo vetado pelo Presidente da República - previa a possibilidade de os demais legitimados para a propositura da ação direta de inconstitucionalidade se manifestarem por escrito sobre o objeto da ação, "no prazo das informações," bem como apresentar memoriais. O "prazo das informações", referido no dispositivo vetado, é de 30 (trinta) dias contados do recebimento do pedido (art. $6^{\circ}$, parágrafo único, da Lei $\mathrm{n}^{\circ} 9.868 / 99$ ).

Cumpre, assim, perquirir como deve ser interpretada a remissão feita pelo $\S 2^{\circ}$ ao prazo mencionado no $\S 1^{\circ}$, que restou vetado.

É de se ver, logo de plano, que o $\S 1^{\circ}$ do art. $7^{\circ}$ cuidava de situação processual substancialmente distinta do que prevê o $\S 2^{\circ}$. No primeiro dispositivo, é fácil notar, instituía o legislador uma prerrogativa dos demais legitimados à propositura da ação direta de intervirem no feito, independentemente de decisão do relator, dentro do prazo estabelecido para a prestação das informações. Já o $2^{\circ}$ prevê a possibilidade de outros órgãos ou entidades intervirem no processo, após despacho (sic) de conteúdo positivo do relator,

poderão ser ouvidos quaisquer outros entes e organizações cuja representatividade autorize a sua manifestação." (BINENBOJM, Gustavo. A Democratização da Jurisdição Constitucional e o Contributo da Lei $n^{\circ}$ 9.868/99. SARMENTO, Daniel (Coord.). O Controle de Constitucionalidade e a Lei $n^{\circ}$ 9.868/99, 2001, p. 159).

33 BINENBOJM, Gustavo. A Nova Jurisdição Constitucional Brasileira. 2. ed. Renovar, 2004, p. 162.

${ }^{34}$ BUENO FILHO, Edgard Silveira, op. cit., p. 6/7.

A \& C R. de Dir. Administrativo e Constitucional, Belo Horizonte, ano 5, n. 19, p. 73-95, jan./mar. 2005 
observado o prazo fixado para as informações.

É dizer: enquanto os demais legitimados poderiam, na forma do $\$ 1^{\circ}$, manifestar-se dentro do prazo das informações, independentemente de qualquer despacho, os demais órgãos ou entidades (não legitimados à propositura) dependeriam de uma decisão do relator, após a qual teriam o mesmo prazo para apresentarem a sua manifestação. Logo, o termo a quo do prazo para a manifestação do terceiro, em um e outro casos, é distinto: no caso do $\S 1^{\circ}$, o termo inicial do prazo era a data do recebimento do pedido de informações; já no caso do $\S 2^{\circ}$, o termo inicial é a data da publicação da decisão que admite a intervenção do amicus curiae.

Tal distinção faz todo sentido na medida em que os "outros órgãos e entidades" dependem, para se manifestarem, de uma decisão de conteúdo positivo do relator. Assim, a fortiori, o prazo só pode começar a fluir a partir da data em que o postulante é formalmente admitido. Não se pode conceber, à evidência, que o prazo para manifestação fluísse antes que o postulante houvesse sido admitido para atuar como amicus curiae.

Dessa forma, a oportunidade processual para a admissão dos amici curiae, nos termos do art. $7^{\circ}, \S 2^{\circ}$, não se exaure com o término do prazo para as autoridades prestarem informações (art. $6^{\circ}$, parágrafo único). Decorre da sistemática da lei que o amicus curiae poderá ser admitido a qualquer tempo, antes de iniciado o julgamento final da ação. O prazo a que se refere o $\$ 2^{\circ}$ do art. $7^{\circ}$ não é para a definição do momento processual da admissão do amicus curiae, mas para a apresentação da sua manifestação escrita a partir da data da decisão positiva do relator.

É neste sentido que apontam a doutrina e a jurisprudência recente do Supremo Tribunal Federal.

Edgard Silveira Bueno Filho assim leciona sobre o assunto, verbis:

(...) a intervenção do amicus curiae pode se dar a qualquer tempo, antes do julgamento da ação. (...) Segundo a lei, deferida a participação do interessado no processo, terá ele o prazo do art. $6^{\circ}$, parágrafo único, para apresentar a sua manifestação, que é de 30 dias. ${ }^{35}$

Antônio do Passo Cabral, seguindo a mesma linha de entendimento, afirma que "têm entendido o STJ e o STF, em nosso sentir com razão, que a intervenção do amicus curiae poderá ocorrer durante a instrução processual, não sendo admissível depois de iniciado o julgamento." 36

Nelson Nery Júnior, a seu turno, leciona que o amicus curiae poderá ${ }_{35}$ BUENO FILHO, Edgard Silveira, op. cit., p. 7.

A \& C R. de Dir. Administrativo e Constitucional, Belo Horizonte, ano 5, n. 19, p. 73-95, jan./mar. 2005 
ser admitido pelo relator não apenas com fulcro no art. $7^{\circ}$, $2^{\circ}$, da Lei $\mathrm{n}^{\circ} 9.868 / 99$, mas também com espeque no art. $9^{\circ}, \S 1^{\circ} .{ }^{37}$ Assim, o ilustre processualista admite a participação do amicus curiae até o final da fase instrutória do processo. ${ }^{38}$

O Supremo Tribunal Federal, por duas vezes, já teve a oportunidade de adotar o entendimento aqui esposado. Em um primeiro caso, nos autos da ADIN n 2.238, a Corte, por maioria, não admitiu a intervenção da Associação Paulista dos Magistrados, na qualidade de amicus curiae, uma vez que a mesma formulara o pedido de admissão no feito depois de já iniciado o julgamento. De acordo com o que consta do Informativo STF $\mathrm{n}^{\circ} 267$, "considerou-se que a manifestação do amicus curiae é para efeito de instrução, não sendo possível admiti-la quando em curso o julgamento." 39

Assim, a contrario sensu, impõe-se entender que a admissão do amicus curiae no processo pode se dar a qualquer tempo, desde que ainda não iniciada a sessão de julgamento. Ressalte-se, entretanto, terem ficado vencidos os Ministros Ilmar Galvão, Carlos Velloso e Sepúlveda Pertence, que entendiam viável a admissão do amicus curiae, mesmo depois de iniciado o julgamento. Tal posição, menos formalista e mais democrática, me parece ser a mais adequada, porquanto permite ao Tribunal ouvir as razões dos terceiros interessados, ainda que apenas via sustentação oral, na sessão de julgamento. De todo modo, vale enfatizar que a Corte Suprema em nenhum momento circunscreveu temporalmente a possibilidade de manifestação do amicus curiae ao prazo das informações, admitindo-a durante a fase instrutória até que iniciado o julgamento da ação direta.

Tal posicionamento pretoriano veio a ser reiterado na $\operatorname{ADIN} n^{\circ}$ 1.104-9 DF, quando o eminente Ministro Gilmar Ferreira Mendes, um dos maiores especialistas do país na matéria, deixou consignado, verbis:

Não obstante a plausibilidade da interpretação adotada na decisão de fl. 73, no sentido de que o prazo das informações seria o marco para a abertura procedimental prevista no art. $7^{\circ}, \S 2^{\circ}$, da Lei ${ }^{\circ} 9.868$, de 1999, cabe reconhecer que a leitura sistemática deste diploma legal remete o intérprete a uma perspectiva pluralista do controle abstrato de normas. Assim, consideradas as circunstâncias do caso concreto, reconsidero a decisão de fl. 73, para admitir a manifestação da Companhia Energética de Brasília, que intervirá no feito na condição de amicus curiae. Fixo o prazo de cinco

\footnotetext{
${ }^{36}$ CABRAL, Antônio do Passo. Pelas Asas de Hermes: a Intervenção do amicus curiae, um Terceiro Especial. Revista de Direito Administrativo (RDA), n. 234, p. 138.

${ }^{37}$ Art. $9^{\circ}, \S 1^{\circ}$ "Em caso de necessidade de esclarecimento de matéria ou circunstância de fato ou de notória insuficiência das informações existentes nos autos, poderá o relator requisitar informações adicionais, designar perito ou comissão de peritos para que emita parecer sobre a questão, ou fixar data para, em audiência pública, ouvir depoimentos de pessoas com experiência e autoridade na matéria."

38 NERY JÚNIOR, Nelson, op. cit., p. 1.408.

${ }^{39}$ ADIN n² 2.238, rel. Min. Ilmar Galvão. Informativo STF, n. 267.
} 
dias para a manifestação. Após o registro, na autuação, do nome da interessada e de seus patronos, publique-se. Brasília, 21 de outubro de 2003. Ministro Gilmar Mendes Relator. ${ }^{40}$ (grifos acrescentados).

Vale destacar que, na decisão acima transcrita, o eminente Ministro Gilmar Mendes reconsiderou seu entendimento anterior, passando a admitir a intervenção do amicus curiae mesmo depois de decorrido o prazo para a prestação das informações. Parece-me, no entanto, que o prazo para que o colaborador informal da Corte apresente as suas razões escritas deva ser, em conformidade com o $\S 2^{\circ}$ do art. $7^{\circ}$, da Lei $n^{\circ} 9.868 / 99$, o mesmo que lei assina para a prestação das informações, no art. $6^{\circ}$, parágrafo único, isto é, 30 (trinta) dias.

\section{Poderes processuais reconhecidos ao interveniente admitido como amicus curiae no controle abstrato: manifestações escrita e oral e legitimidade recursal}

Como já anteriormente referido, mesmo antes do advento da Lei n 9.868/99, o Supremo Tribunal Federal já admitia, informalmente, que terceiros interessados apresentassem memoriais à Corte sobre o objeto de ação direta de inconstitucionalidade em curso. Sem o embasamento da prescrição legal agora positivada no art. $7^{\circ}$, $\S 2^{\circ}$, da aludida Lei, o STF, permeável às influências do direito norte-americano, admitiu, por diversas vezes, que memoriais fossem entregues nos gabinetes dos Ministros e até juntos por linha aos autos, sem, no entanto, que tal configurasse ingresso regular e formal na relação processual pela ação direta..$^{41}$

A inovação trazida pelo art. $7^{\circ}, \S 2^{\circ}$, da Lei n ${ }^{\circ} 9.868 / 99$ é relevante e substantiva. O novel dispositivo, com efeito, deu ao amicus curiae o tratamento de um terceiro especial, com direito a ingressar formalmente na relação processual, pela juntada de sua manifestação escrita aos autos, assumindo determinadas prerrogativas processuais inerentes à sua condição. O sentido da vedação genérica contida no caput do art. $7^{\circ}$ ("Não se admitirá intervenção de terceiros no processo de ação direta de inconstitucionalidade") é, tão-somente, a de impedir o manejo, em sede de controle abstrato, das modalidades de intervenção de terceiros previstas no Código de Processo Civil (arts. 50 e segs.). ${ }^{42}$

A doutrina e a jurisprudência caminham no sentido acima apontado. O eminente Ministro Milton Luiz Pereira, do Superior Tribunal
${ }^{40}$ ADIN n $1.104-9$ DF, rel. Min. Gilmar Mendes. DJ 29.10.2003, p. 00033 , do
${ }^{41}$ V., neste sentido, O Agravo Regimental na ADIN n'748-4 RS, rel. Min. Celso de Mello. DJ, 18.11.94,
p. 31.392 .

A \& C R. de Dir. Administrativo e Constitucional, Belo Horizonte, ano 5, n. 19, p. 73-95, jan./mar. 2005 
de Justiça, afirma que o amicus curiae é um "terceiro especial ou de natureza excepcional", não se confundindo com a assistência ou qualquer outra forma de intervenção de terceiros prevista no Código de Processo Civil. ${ }^{43} \mathrm{O}$ Superior Tribunal de Justiça, por seu turno, tem admitido a intervenção de agências reguladoras em processos intersubjetivos, na qualidade de terceiro especial (amicus curiae). ${ }^{44}$

O Supremo Tribunal Federal, interpretando o art. $7^{\circ}$, $§ 2^{\circ}$, da Lei $\mathrm{n}^{\circ}$ 9.868/99, compreendeu o sentido da transformação do instituto do amicus curiae operada pela nova legislação, que de colaborador informal da Corte foi convolado em verdadeiro terceiro especial. Confira-se o teor literal do pronunciamento do STF, por intermédio do eminente Ministro Celso de Mello:

No estatuto que rege o sistema de controle normativo abstrato de constitucionalidade, o ordenamento positivo brasileiro processualizou a figura do amicus curiae (Lei ${ }^{\circ} 9.868 / 99$, art. $7^{\circ}, \S 2^{\circ}$ ), permitindo que terceiros - desde que investidos de representatividade adequada — possam ser admitidos na relação processual, para efeito de manifestação sobre a questão de direito subjacente à própria controvérsia constitucional.

A admissão de terceiro, na condição de amicus curiae, no processo objetivo de controle normativo abstrato, qualifica-se como fator de legitimação social das decisões da Suprema Corte, enquanto Tribunal Constitucional, pois viabiliza, em obséquio ao postulado democrático, a abertura do processo de fiscalização concentrada de constitucionalidade $(. . .)^{45}$

Como se vê, muito mais que um mero colaborador informal, o amicus curiae, tal como disciplinado pela Lei ${ }^{\circ}$ 9.868/99, intervém nos autos do processo da ação direta, passando a integrar a relação processual na condição de terceiro especial.

Assim, a primeira prerrogativa processual que se reconhece ao amicus curiae é a de apresentar manifestação escrita sobre as questões de seu interesse atinentes à ação direta em curso, que será junta aos autos do processo. Por evidente, como nenhum instituto processual pode ser presumido inútil, a juntada aos autos da manifestação escrita do amicus curiae merecerá, da parte da Corte, a devida consideração e enfrentamento, ainda que, ao final,

\footnotetext{
42 Neste sentido, CABRAL, Antônio do Passo, op. cit., p. 118.

${ }^{43}$ PEREIRA, Milton Luiz. Amicus Curiae - Intervenção de Terceiros. Revista de Informação Legislativa, ano 39, n. 156 , out./dez. 2002, p. 9/11.

${ }^{44}$ Agravo Regimental na Petição n 1.621/PE, Corte Especial, j. 02.05.2002; Agravo Regimental no Resp n 326.097/CE - Rel. Min. Milton Luiz Pereira, j. 02.05.2002.

${ }^{45}$ ADIN n² 2.130-3 SC, rel. Min. Celso de Mello. Informativo STF, n. 215. DJ, 02.02.2001.
} 
suas ponderações sejam inteiramente descartadas. Eis aqui uma primeira e relevante inovação trazida pelo art. $7^{\circ}, \S^{\circ}$, da Lei $n^{\circ}$ 9.868/99: ao contrário do memorial entregue nos gabinetes dos magistrados pelo colaborador informal (como ocorria antes), a manifestação escrita do amicus curiae consta formalmente dos autos, não podendo ser simplesmente ignorada pelo Tribunal.

Mas os poderes processuais do amicus curiae não se cingem à apresentação de razões escritas.

No que toca à possibilidade de realização de sustentação oral, pelo patrono do amicus curiae, o Supremo Tribunal Federal recentemente reviu seu posicionamento anterior, passando a admiti-la. De fato, no ano de 2000, o então Presidente do STF, Ministro Carlos Velloso, proferiu decisão monocrática nos autos da ADIN n 2.321-DF, na qual entendia não ser possível a realização de sustentação oral pelo advogado do amicus curiae.$^{46} \mathrm{Em} 2001$, a Corte, por sua formação plenária, ratificou o entendimento do eminente Ministro Carlos Velloso, indeferindo o pleito de sustentação oral formulado pelo patrono do amicus curiae admitido no feito. Ficaram vencidos, quanto à questão, os Ministros Nelson Jobim, Celso de Mello e Marco Aurélio. ${ }^{47}$

Recentemente, todavia, em novembro de 2003, o Supremo Tribunal reviu seu entendimento anterior e, por maioria, vencidos apenas os Ministros Carlos Velloso e Ellen Gracie, passando a admitir a realização de sustentação oral pelos advogados de amici curiae regularmente habilitados nos autos do processo de ação direta. ${ }^{48}$ Em seu importante voto para o desfecho da questão, lavrou o eminente Ministro Celso de Mello, verbis:

(...) entendo que a atuação processual do amicus curiae não deve limitar-se à mera apresentação de memoriais ou à prestação eventual de informações que lhe venham a ser solicitadas.

Essa visão do problema — que restringisse a extensão dos poderes processuais do "colaborador do Tribunal" - culminaria por fazer prevalecer, na matéria, uma incompreensível perspectiva reducionista, que não pode (nem deve) ser aceita por esta Corte, sob pena de total frustração dos altos objetivos políticos, sociais e jurídicos visados pelo legislador na positivação da cláusula que, agora, admite o formal ingresso do amicus curiae no processo de fiscalização concentrada de constitucionalidade.

Cumpre permitir, desse modo, ao amicus curiae, em extensão maior, o exercício de determinados poderes processuais, como aquele consistente no direito de proceder à sustentação oral das razões que justificaram a sua admissão formal na causa.

\footnotetext{
${ }^{46}$ ADIN n² 2.321-DF, rel. Min. Carlos Velloso. Informativo STF, n. 208.

${ }^{47}$ ADIN n².223-DF, rel. Min. Marco Aurélio. Informativo STF, n. 246

${ }^{48}$ ADIN n².777-SP, rel. Min. Cezar Peluso. Informativo STF, n. 331.
}

A \& C R. de Dir. Administrativo e Constitucional, Belo Horizonte, ano 5, n. 19, p. 73-95, jan./mar. 2005 
(grifos do original). ${ }^{49}$

O direito à realização da sustentação oral, assim, se apresenta como uma extensão natural, corolário lógico da admissão formal do amicus curiae como terceiro especial. Uma vez considerados presentes pela Corte os requisitos estabelecidos no art. $7^{\circ}, \S 2^{\circ}$, da Lei $n^{\circ} 9.868 / 99$, isto é, a representatividade do postulante e a relevância da matéria subjacente à ação direta de inconstitucionalidade, não há como se negar ao amicus o direito à sustentação oral de suas razões, tanto como à sua expressão escrita.

Milita em favor de tal entendimento, como realçado pelo eminente Ministro Celso de Mello, o sentido finalístico da norma em questão, que é o de democratizar o processo de controle concentrado de constitucionalidade, dando voz não apenas às partes formais do feito, mas também aos órgãos ou entidades representativas da sociedade civil que possam vir a sofrer a repercussão da decisão a ser proferida na ação.

Por outro lado, o art. $10, \S 2^{\circ}$, da Lei $n^{\circ} 9.868 / 99$ prevê apenas que será facultada sustentação oral aos representantes judiciais do requerente e das autoridades ou órgãos responsáveis pela expedição do ato, sem qualquer conteúdo vedatório a que terceiros possam vir a fazê-lo. Assim, parece evidente que tal dispositivo não veda, por exemplo, a manifestação oral do Procurador-Geral da República ou do Advogado-Geral da União, embora não sejam estes requerentes ou representantes judiciais dos requeridos na ação direta. De igual modo, não veda o dispositivo que os amici curiae tenham suas razões sustentadas oralmente por seus advogados nas sessões de julgamento.

Ademais, o $\S 2^{\circ}$ do art. $7^{\circ}$, ao contrário do que fazia o $\S 1^{\circ}$ do mesmo art. $7^{\circ}$ — que acabou sendo vetado — não restringe a manifestação do amicus curiae a peças escritas. De fato, do contraste entre o $\S 1^{\circ}$ e o $\S 2^{\circ}$ contata-se nitidamente que a mens legislatoris foi a de permitir a manifestação do amicus curiae tanto pela via escrita como pela via oral.

Consignada, assim, as faculdades de o amicus curiae manifestar-se por escrito ou oralmente, resta examinar a possibilidade de o amicus curiae insurgir-se contra as decisões proferidas no curso e ao final da ação direta, através dos recursos cabíveis.

Cumpre, em primeiro lugar, examinar a possibilidade de o postulante

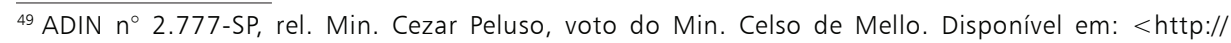
conjur.uol.com.br/textos/23254>.
}

A \& C R. de Dir. Administrativo e Constitucional, Belo Horizonte, ano 5, n. 19, p. 73-95, jan./mar. 2005 
a amicus curiae se insurgir, pela via recursal própria, contra a decisão do relator que não o admite no feita em tal qualidade. Vale, neste passo, relembrar a dicção literal do art. $7^{\circ}, \S 2^{\circ}$, que reza:

$\S 2^{\circ} \mathrm{O}$ relator, considerando a relevância da matéria e a representatividade dos postulantes, poderá, por despacho irrecorrível, admitir, observado o prazo fixado no parágrafo anterior, a manifestação de outros órgãos ou entidades.

A previsão da irrecorribilidade da decisão do relator se aplica, por óbvio, àquelas decisões de conteúdo positivo, pois o dispositivo menciona expressamente apenas como "despacho irrecorrível" (rectius: trata-se de decisão interlocutória, e não de mero despacho) ${ }^{50}$ a decisão que admite a manifestação do amicus curiae. As decisões de conteúdo negativo - indeferitórias do ingresso formal do amicus — podem, à evidência, ser impugnadas pelo interessado através do recurso cabível de agravo regimental.

Há, entretanto, no mínimo três sólidos argumentos em favor desse entendimento, que se somam, com especial relevância, ao argumento puramente literal.

O primeiro argumento, formulado a partir da regra elementar de hermenêutica segundo a qual as interpretações demandam previsão expressa e devem ser interpretadas restritivamente. É dizer: como exceção à regra geral da recorribilidade das decisões, a irrecorribilidade deve ser interpretada restritivamente, para alcançar apenas as decisões de conteúdo positivo.

O segundo argumento, derivado da lógica e da sistemática processual, porquanto, ao contrário das decisões de conteúdo positivo, as decisões denegatórias do ingresso do amicus curiae causam um agravo específico ao postulante. Assim, havendo sofrido um agravo em seu suposto direito, há que ser reconhecido ao postulante o direito de obter o pronunciamento do colegiado a respeito de sua postulação.

Por fim, o terceiro argumento, baseado em uma filtragem constitucional do texto do art. $7^{\circ}, \S 2^{\circ}$. Com efeito, por uma interpretação conforme à Constituição do dispositivo, que prestigie o direito ao contraditório e à ampla defesa, bem como a garantia do devido processo legal, há que se lhe dar a inteligência mais benéfica aos postulantes, permitindo-se-lhes que, por meio de agravo regimental, submetam a decisão indeferitória do relator ao Plenário da Corte.

Resta, ainda, indagar da possibilidade de o amicus curiae recorrer

$\overline{50}$ Neste sentido, NERY JÚNIOR, Nelson, op. cit., p. 1.409.

A \& C R. de Dir. Administrativo e Constitucional, Belo Horizonte, ano 5, n. 19, p. 73-95, jan./mar. 2005 
das demais decisões — interlocutórias e final — proferidas nos autos da ação direta.

$\mathrm{O}$ art. 499 do Código de Processo Civil assegura legitimidade recursal ao Ministério Público e ao terceiro prejudicado. Reconhecendo, hoje, a doutrina e a jurisprudência, a natureza jurídica de terceiro especial ao amicus curiae, não há como se lhe negar a legitimidade recursal para manifestar sua insurgência contras as decisões que não acolherem seus argumentos.

Ensina Sérgio Bermudes que a finalidade dos recursos é a de proporcionar o "aperfeiçoamento das decisões judiciais." ${ }^{51}$ Assim, não há motivo lógico para que ao amicus curiae seja assegurado o direito de apresentar seus argumentos, por escrito e oralmente, perante o Tribunal e, como desdobramento natural, não possa se insurgir contra as decisões que contrariem tais argumentos, por meio dos recursos cabíveis. É evidente que, em sede de controle de constitucionalidade, tal aperfeiçoamento se torna ainda mais desejável. De fato, diante do impacto e da repercussão política, econômica e social de uma decisão declaratória de inconstitucionalidade, é ainda maior o interesse do Estado-Jurisdição e da sociedade como um todo no sentido de que as decisões sejam submetidas ao mais rígido escrutínio.

A referência ao "terceiro" do art. 499 do Código de Processo Civil "designa o estranho ao processo, titular da relação jurídica atingida (ainda que por via reflexa) pela sentença" ${ }^{52}$ É evidente que as entidades e órgãos que eventualmente venham a figurar como amicus curiae, podem sofrer impactos diretos em razão da decisão em controle abstrato, podendo, até mesmo, perder direitos antes reconhecidos pela lei atacada. Dessa forma, o amicus curiae é titular de um direito passível de ser atingido - ao menos potencialmente - por acórdão declaratório de inconstitucionalidade, possuindo, assim, legitimidade recursal como terceiro interessado, aplicando-se, analogicamente, o art. 499 do CPC.

Deve-se destacar, todavia, que, mesmo a se entender que não haja, num caso qualquer, impacto direto sobre direito subjetivo do amicus curiae, haverá legitimidade recursal deste, pois, para que seja o terceiro apto a recorrer, "basta que a sua esfera jurídica seja atingida pela decisão, embora por via reflexa", ${ }^{53}$ o que, evidentemente, sempre ocorrerá.

\footnotetext{
${ }^{51}$ BERMUDES, Sérgio. Comentários ao Código de Processo Civil. 2. ed. Revista dos Tribunais, v. VII, p. 22.

52 MOREIRA, José Carlos Barbosa. O Novo Processo Civil Brasileiro. 21. ed. Rio de Janeiro: Forense, 2001, p. 117.
}

A \& C R. de Dir. Administrativo e Constitucional, Belo Horizonte, ano 5, n. 19, p. 73-95, jan./mar. 2005 
Ademais, é interessante notar que a participação do amicus curiae, que já era aceita antes mesmo do advento da Lei 9868/99, é, fundamentalmente, uma decorrência do princípio democrático. Pode-se dizer, assim, que a intervenção do amicus curiae, com os meios e recursos próprios assegurados aos terceiros em geral, representa garantia do exercício democrático da jurisdição constitucional. Em síntese, a intervenção do amicus curiae constitui uma das múltiplas faces da garantia do acesso à Justiça (CF, art. $\left.5^{\circ}, \mathrm{XXXV}\right)$ no âmbito de um Estado Democrático de Direito (CF, art. $1^{\circ}$ ).

Está, assim, o amicus curiae legitimado a manejar o agravo regimental contra decisões interlocutórias do relator, bem como os embargos de declaração contra os acórdãos cautelares e de mérito. Ademais, no plano do controle abstrato estadual, além dos recursos já mencionados, poderá o amicus curiae valer-se dos recursos especial e extraordinário, conforme seja o caso de cabimento de um ou outro. Tal elenco recursal é, por óbvio, meramente exemplificativo, sendo lícito ao amicus curiae interpor qualquer recurso cabível, de acordo com a legislação processual.

Por derradeiro, além das prerrogativas processuais até aqui mencionadas, poderá o amicus curiae suscitar, perante o relator, a adoção das providências instrutórias previstas no art. $9^{\circ}, \S \S 1^{\circ}, 2^{\circ}$ e $3^{\circ}$, da Lei $n^{\circ} 9.868 / 99$. Confira-se o teor do dispositivo, verbis:

Art. $9^{\circ}$ Vencidos os prazos do artigo anterior, o relator lançará o relatório, com cópia a todos os Ministros, e pedirá dia para julgamento.

$\S 1^{\circ}$ Em caso de necessidade de esclarecimento de matéria ou circunstância de fato ou de notória insuficiência das informações existentes nos autos, poderá o relator requisitar informações adicionais, designar perito ou comissão de peritos para que emita parecer sobre a questão, ou fixar data para, em audiência pública, ouvir depoimentos de pessoas com experiência e autoridade na matéria.

$\S 2^{\circ} \mathrm{O}$ relator poderá, ainda, solicitar informações aos Tribunais Superiores, aos Tribunais federais e aos Tribunais estaduais acerca da aplicação da norma impugnada no âmbito de sua jurisdição.

$\S 3^{\circ}$ As informações, perícias e audiências a que se referem os parágrafos anteriores serão realizadas no prazo de trinta dias, contado da solicitação do relator.

A dicção do dispositivo é clara: poderá o relator adotar uma ou algumas de tais providências instrutórias, de oficio, previamente ao julgamento final da ação. Ora, se o relator pode ex officio determinar quaisquer daquelas providências, os interessados admitidos nos autos -

\footnotetext{
${ }^{53}$ MOREIRA, José Carlos Barbosa. Comentários ao Código de Processo Civil. 9. ed. Rio de Janeiro: Forense, 2001, v. V, p. 294.
}

A \& C R. de Dir. Administrativo e Constitucional, Belo Horizonte, ano 5, n. 19, p. 73-95, jan./mar. 2005 
representante, representados, Advogado-Geral da União, Procurador-Geral do Estado, Ministério Público, amicus curiae - poderão, a qualquer tempo antes do julgamento, requerer a sua adoção. $\mathrm{O}$ amicus curiae recebe o feito no estado em que se encontra quando de sua admissão; não havendo se iniciado, ainda, o julgamento final da causa, poderá ele requerer as providências instrutórias que lhe parecerem relevantes para o deslinde da questão constitucional.

\section{Síntese conclusiva}

A Lei Federal n 9.868/99 estabelece normas gerais aplicáveis ao processo de controle abstrato de constitucionalidade, tanto em nível federal como estadual, por força do que dispõem o art. 22, inciso I e o art. 24, inciso IX e $\S 1^{\circ}$, da Constituição da República. $\mathrm{O}$ art. $7^{\circ}, \S 2^{\circ}$, da referida Lei - aplicável, como se disse, tanto às ações diretas de inconstitucionalidade ajuizadas perante o Supremo Tribunal Federal, como às representações por inconstitucionalidade propostas perante os Tribunais de Justiça dos Estados - assegura a órgãos ou entidades, considerada a sua representatividade e a relevância da matéria em discussão, o direito de intervirem, na qualidade de amicus curiae, nos autos de processo de controle abstrato de constitucionalidade.

Têm legitimidade para intervir como amicus curiae tanto os legitimados para a propositura de ADI a que se refere o art. $2^{\circ}$ da Lei $n^{\circ} 9.868 / 99$, quanto outras entidades e órgãos que, por sua notória representatividade e à vista da relevância da matéria, mereçam manifestar-se no processo para torná-lo mais democrático. Essa é uma conclusão a que se chega através de uma singela interpretação sistemática do $\S 2^{\circ}$ em cotejo com o $\S 1^{\circ}$ (vetado) do art. $7^{\circ}$ da Lei $n^{\circ} 9.868 / 99$. Deveras, enquanto o $\S 1^{\circ}$ do dispunha que "os demais titulares referidos no art. $2^{\circ}$ poderão manifestar-se, por escrito, sobre o objeto da ação...”, o §2 se refere à manifestação de “outros órgãos ou entidades”.

Daí só pode decorrer, logicamente, que o legislador cogitou, no $\S 1^{\circ}$, de permitir a atuação, como amici curiae, dos demais legitimados à propositura da ação direta, enquanto, no $\S 2^{\circ}$, permitiu a intervenção de outros órgãos ou entidades que não se qualifiquem como legitimados a tal propositura, mas que, por sua notória representatividade e à vista da relevância da matéria, mereçam manifestar-se no processo. Tal entendimento tem a chancela da jurisprudência pacífica do Supremo Tribunal Federal.

A intervenção do amicus curiae em processos de controle abstrato de

A \& C R. de Dir. Administrativo e Constitucional, Belo Horizonte, ano 5, n. 19, p. 73-95, jan./mar. 2005 
constitucionalidade, tanto federais como estaduais, pode dar-se a qualquer tempo, até que iniciado o julgamento final da ação. O $\S 2^{\circ}$ do art. $7^{\circ}$ da Lei $\mathrm{n}^{\circ}$ 9.868/99 estabelece que a manifestação do amicus curiae, já admitido nos autos por decisão do relator, deverá ser apresentada no prazo das informações previsto no art. $6^{\circ}$, parágrafo único, da mesma Lei, isto é, 30 (trinta) dias. Este, portanto, é o prazo processual para a protocolização da manifestação escrita do amicus curiae, não o termo final do momento processual oportuno para a sua postulação de ingresso nos autos.

De acordo com autorizado magistério da doutrina e a jurisprudência recente do Supremo Tribunal Federal, a postulação de intervenção nos autos da ação direta (ou representação por inconstitucionalidade), na condição de amicus curiae, pode se dar, como se assentou, até a fase final da instrução processual, mas antes de iniciado o julgamento final da causa. Já o prazo para a manifestação escrita do amicus é de 30 (trinta) dias contados da data da publicação da decisão do relator que admite a sua intervenção no feito.

Além da apresentação de memoriais escritos (briefs), que serão juntos aos autos do processo, o amicus curiae poderá, através de seu advogado regularmente constituído nos autos, exercitar o direito à realização de sustentação oral nas sessões de julgamento das representações por inconstitucionalidade. Tal entendimento, que decorre de uma interpretação sistemática da Lei $n^{\circ}$ 9.868/99 e do seu espírito pluralista e democrático, mereceu o beneplácito recente do Supremo Tribunal Federal.

Com relação ao direito à insurgência recursal, tem o postulante o direito de recorrer, primariamente através de agravo regimental, contra a decisão do relator que indefira a sua intervenção nos autos, na qualidade de amicus curiae.

A previsão da irrecorribilidade da decisão do relator, constante do art. $7^{\circ}, \S 2^{\circ}$, da Lei $n^{\circ} 9.868 / 99$, se aplica, por óbvio, tão-somente àquelas decisões de conteúdo positivo, pois o dispositivo menciona expressamente como "despacho irrecorrível" (rectius: trata-se de decisão interlocutória, e não de mero despacho) $)^{54}$ apenas a decisão que admite a manifestação do amicus curiae. As decisões de conteúdo negativo - indeferitórias do ingresso formal do amicus — podem, à evidência, ser impugnadas pelo interessado através do recurso cabível de agravo regimental.

Como exceção à regra geral da recorribilidade das decisões, a irrecorribilidade deve ser interpretada restritivamente, para alcançar apenas as decisões de conteúdo positivo. Além disso, ao contrário das decisões de 
conteúdo positivo, as decisões denegatórias do ingresso do amicus curiae causam um agravo específico ao postulante. Assim, havendo sofrido um agravo em seu suposto direito, há que ser reconhecido ao postulante o direito de obter o pronunciamento do colegiado a respeito de sua postulação.

Finalmente, por uma interpretação conforme à Constituição do art. $7^{\circ}$, $\S 2^{\circ}$, que prestigie o direito ao contraditório e a ampla defesa, bem como a garantia do devido processo legal, há que se lhe dar a inteligência mais benéfica ao amicus curiae, permitindo-se-lhes que, por meio de agravo regimental, submeta a decisão indeferitória do relator ao Plenário da Corte.

Anote-se, por derradeiro, que, como terceiro especial admitido nos autos, está o amicus curiae legitimado a manejar os recursos processuais cabíveis, consoante o art. 499 do Código de Processo Civil, podendo ainda requerer a adoção das providências instrutórias previstas no art. $9^{\circ}, \S \S 1^{\circ} \mathrm{e}$ $2^{\circ}$, da Lei ${ }^{\circ} 9.868 / 99$.

Informação bibliográfica deste texto, conforme a NBR 6023:2002 da Associação Brasileira de Normas Técnicas (ABNT):

BINENBOJM, Gustavo. A dimensão do amicus curiae no processo constitucional brasileiro: requisitos, poderes processuais e aplicabilidade no âmbito estadual. A $\mathcal{E}^{2} \mathrm{C}$ Revista de Direito Administrativo e Constitucional, Belo Horizonte, ano 5, n. 19, p. 73-95, jan./mar. 2005.

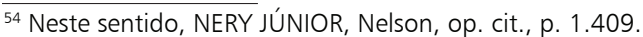

A \& C R. de Dir. Administrativo e Constitucional, Belo Horizonte, ano 5, n. 19, p. 73-95, jan./mar. 2005 